\title{
"Ritual" in Recent Criticism: The Elusive Sense of Community
}

\section{A}

READER OF modern criticism learns to live with uncertainty when encountering some of the most ordinary terms. Words like "symbol," "rhythm," or "irony" require our patience, our openness to an unpredictable set of theoretical assumptions. Not many readers are so fastidious as to demand a new word for every shade of difference from an "accepted" meaning, and this is probably a healthy condition. "The abuse of an old word, if explained, may give less trouble than the invention of a new," writes C. S. Lewis (550). The mania for new phraseology has not always helped the social sciences, and there is no reason to think it would advance the understanding of literature. Still, explanations should be forthcoming when words undergo their necessary abuse. What, for example, does it mean to call a literary work a ritual? Some of the most reputable critics over the past decade have said that Milton's Lycidas is "a mourning ritual" (Wittreich 98), that Goethe's Faust "is an exceptionally clear instance of the work of art conceived as a socializing rite de passage" (Hartman, Fate 110), that Eliot's "Love Song of J. Alfred Prufrock" ends "with a ritual drama of rolling the universe toward an overwhelming question" (Feder 221), that a minor Jacobean play exemplifies the principle that "poetry is a ritual of resurrection and rebirth" (Cope 174). For the most part these statements are illuminating when read in the context of their arguments, so it would be churlish to accuse the authors of irresponsibility. "Ritual," however, has become a wonderfully unstable and intriguing word, owing, as I hope to show, to developments in our understanding of both ritual and literature over the past ten or fifteen years.

The use of "ritual" has quite properly been associated with myth criticism, but if we examine John B. Vickery's classic collection of essays in this field, Myth and Literature, we may find that as late as the 1960s myth critics held certain notions about ritual that are no longer ten- able. Stanley Edgar Hyman's 1958 essay in that collection stands as the most confident assertion of these beliefs. A great student of Darwin's prose, Hyman seems to view literary theory as undergoing its own modest evolution within the larger progress of the human sciences, from $\mathrm{E}$. B. Tylor's Primitive Culture to James G. Frazer's Golden Bough and the applications of Frazer by the so-called Cambridge school of criticism (Jane Harrison, Gilbert Murray, A. B. Cook, and F. M. Cornford). Since the 1960s virtually every "discovery" that Hyman attributes to this movement has been seriously challenged. Few people believe that all myth, including the bulk of Homer and "the whole body of Near East sacred literature" (51), originates in ritual. Few classical scholars would now say that "the ritual view has illuminated almost the whole of Greek culture" (56) or even that "the forms of Attic tragedy arise out of sacrificial rites of tauriform or aegiform Dionysos" (57). Although the ritual origins of drama in general are not so readily assumed as they were in $\mathrm{Hy}-$ man's day, it remains true that, as Heinrich Dörrie observes, the specialist criticism of classicists "has not sufficiently prevailed in those areas in which more than one area of scholarship connect (ethnology, religious studies, psychology). In these fields it is still true that whatever pleases is allowed" (129, n. 13). The most influential developments of Frazer and the Cambridge school came, of course, not from Hyman but from Northrop Frye, whose elegant theories of myth, genre, mode, and archetype promoted a rich harvest of myth criticism in the 1960s. Still, Frye's assumptions are not all that different from Hyman's. At least one advance in myth criticism, and in our perceptions of "ritual" in literature, has come since Frye, in the theories of René Girard, whose ideas often resemble Frye's in their comprehensiveness, though they usually lead to conclusions diametrically opposed to his.

In this essay I propose that many critics of the 
last ten or fifteen years have still not come to terms with the meaning of "ritual," often because they base their assumptions on outdated notions about the origins of myth in ritual, about the connections between Greek or medieval drama and ritual, or about narrative as displaced ritual. It needs to be more generally known that these subjects have undergone serious reexamination in the last few years and that the very concept of ritual (or ceremony-I use the terms interchangeably, as indeed most scholars do) has received much scrutiny in the social sciences during the same period. One particular theory, that of Victor Turner, has received wide acceptance, and I propose it as the most adequate for criticism today. Besides its clarity and precision, the theory has the advantage of recognizing the social foundations of ritual, a characteristic that critics have often overlooked. Rites cannot exist in an aesthetic or formalist vacuum; they require the context of community. We do not invent the great ceremonies of our culture but, rather, come to them as parts of a whole. Although rites may share their symbolic nature with art, they convey the sense of satisfaction peculiar to them alone in the intense experience of community that is their chief reason for being. The first two sections of the essay summarize some important new insights into relations between literature and ritual since midcentury and some of the ideas recently brought to bear on the subject by the social sciences. The third section surveys criticism, chiefly of the 1970 s, that employs ritual as a central concept. I make no pretensions to have covered all literary studies, however, and in fact have had to leave out some items that, worthwhile in themselves, are not sufficiently relevant to my essay. There are critics, I believe, who have dealt quite aptly with this subject, though they may show no signs of having read anthropology; it is from them, perhaps, that we have the most to learn.

\section{I}

We can attribute many assumptions regarding a ritual element in literature to the influence of handbooks, anthology introductions, and such widely read critical works as Francis Fergusson's Idea of a Theater and those of Frye. These perpetuate the view that Greek tragedy origi- nated in primitive Greek ritual, with the corollary that other forms of drama, perhaps all drama, had such roots. Jane Harrison believed that drama was related to dromenon, "the thing done" in a rite, which had a corresponding myth or legomenon, "thing spoken" (Hyman, "Ritual" 48-49). Thus the ritual theory of myth arises simultaneously with the ritual theory of drama, so that discussion of one inevitably leads to the other.

Of the many classical scholars who now dispute the ritual origins of tragedy none is more convincing or more aware of the implications of the theory for criticism at large than Gerald F. Else, whose Origins and Early Form of Greek Tragedy takes up the cudgels where Sir Arthur Pickard-Cambridge left off. ${ }^{1}$ From the beginning, Else is alarmed that so influential a book as The Idea of a Theater would depend so fully on the exploded ideas of the Cambridge school, whose theory of tragedy "is not now held, at least in its strictest form, by any leading scholar." The disrepute of this theory "appears to have been unknown to Fergusson, and it is certainly unknown to many others" (3). Else's book questions, if it does not exactly overturn, many handbook truisms about tragedy. On the "Dionysiac" element, Else claims that nothing known about the history of early tragedy implies a Dionysiac content (31); he reminds us that Aristotle's Poetics never mentions the god or the spirit Dionysus is supposed to represent (14). As for the later plays,

The content of the overwhelming majority of known tragedies (and we know the title and/or content of many more than are now extant) is heroic myth and legend, from Homer and the epic cycle. Affiliations with cult-myths and cult-rituals, especially those of Dionysos, are secondary both in extent and importance. In other words the regular source of tragic material is heroic epic, not religious cult.

The self-awareness of the Greek tragic hero as we know him "is at the opposite pole from the Dionysiac frenzy of self-abandonment" (69). Skeptical of the belief that literary forms like tragedy must "evolve," Else poses the equally credible hypothesis that tragedy was invented in two successive acts of genius: first by Thespis, who created tragoidia (not, in the received 
sense, derived from "goat-song" $[25,70])$. This was a "self-presentation" by a single epic hero in his moment of pathos. After Thespis invented this recitative event, Aeschylus, adding the second character, gave us tragic drama $(65,78)$.

Else mentions a number of European scholars who have rejected the ritual theory, including Albin Lesky, C. del Grande, and Harold Patzer; in this country he might have added Bernard Knox $(6,71)$, William Arrowsmith, and Oliver Taplin, among others. Taplin is one of many classicists who have reminded us that the requirement for sameness marks ritual as distinct from dramatic art; Greek tragedies are not the same, as anyone knows who has tried to apply the Aristotelean model to, say, Sophocles' Philoctetes. Indeed, "The break with the repetitiousness of ritual may well have been one of the great achievements of tragedy's creators" (Greek Tragedy 161). Else wrote at a time when the old order was passing-Jessie Weston, William Troy, Fergusson, Theodor Gaster, Richard Chase, Hyman, and Lord Raglan-and if we are to accept his arguments we may find that to learn anything about tragedy from the examination of ritual we must, as Michael Hinden says, study the two forms as analogous, not interdependent. ${ }^{2}$

A notion that Else finds especially scandalous is the modern belief that Greek audiences approached tragedy in a spirit of "ritual expectancy," a critical assumption that "does serious damage to our interpretation of the plays and through them to our conception of tragedy as a whole" (4). This view, however, has influenced theatrical productions and criticism alike, as anyone knows who has seen Tyrone Guthrie's celebrated film of Oedipus. Bernard Knox finds fault with that production, and Oliver Taplin, in a recent survey of Greek tragedies on film, suggests that those who liked the Guthrie version "were impressed in the way that one might be by witnessing the dances and rituals of some primitive tribe, though with no notion of their significance" ("Delphic Idea" 811). The strangeness of the film creates a response in the audience, but-and the issue will recur in this discussion -it remains to be seen whether the sense of awe or transcendence is equivalent to a response to the work as drama. On the whole, Else gives us cause to rethink, if not to reject outright, the notion of "ritual expectancy" in drama. Anthony Graham-White proposes that it is just in the matter of expectations that ritual differs from drama. Rituals are believed to be efficacious; they never exist for their own sake. It will not do, Graham-White maintains, to equate audience participation with ritual. Rites in traditional societies "usually are carried out by a clearly defined group," with the general public carefully excluded (323)..$^{3}$

On the whole it seems that the ritual hypothesis does more violence to the evidence than do some of the less exciting proposals of later classical scholarship. Furthermore, there is much to be said for the idea that the form and purpose of rites differ from those of drama, especially tragedy. A rite can be carried on by a single "actor"; the audience seldom identifies itself with a ritual celebrant in a spirit of pathos as it does when watching an actor; even when the audience knows the "fable" behind a play, it does not know how the expected end will be reached, though such familiarity is often required in ritual, and innovation is sure to arouse controversy. Victor Turner, Margaret Mead, and other anthropologists have declared the smallest unit of ritual to be the symbol. ${ }^{4}$ If so, then perhaps in those dramas that are most frequently seen as ritualistic we focus on the symbols rather than on the hero's pathos or the development of plot (Fichte 15; quoted in Flanigan's second article, $115) .^{5}$ Although Oedipus is a well-plotted mimetic drama, the richness of the symbolism almost justifies Guthrie's treatment: one thinks of plague, blindness, the crossroads, the shepherd-king, the lame savior, incest, and countless other images in the language and action of the play hinting at a latent meaning of far greater consequence than the experienced events. Ritual drama is thinly plotted, but like much Greek tragedy it creates deep emotion through the use of symbols. Yeats, who called his own plays "not drama but the ritual of a lost faith," wrote with great success in this way, using incantatory language, masks, and archetypal characters "to draw the audience away from daily life and into the deeper levels of contemplation and response" (Gorsky 176). Yet because no theory of tragedy has ever elevated the symbol to so crucial a place in the genre, we may question whether the ritual hypothesis serves as useful a 
purpose in criticism of drama, particularly tragedy, as scholars once thought.

Although the ritual theory of myth, like that of tragedy, was already in the air during the later nineteenth century, we may trace its debut in English literary studies to the year 1890, when William Robertson Smith's Religion of the Semites, Jane Harrison's Mythology and Monuments of Ancient Athens, and Frazer's Golden Bough all first saw publication. To an outsider the theory that all myths derive from rituals may seem needlessly reductive, so that Clyde Kluckhohn's well-known critique of the theory in 1942 would appear to right the balance on behalf of common sense. Other serious flaws in the theory came to light during the next two decades, as in Joseph Fontenrose's book on the Delphic myth, which shows that the Babylonian myth of beginnings as told in the Enuma elish was recited in the Akitu festival but not enacted or symbolized in the rites of the occasion (ch. 15) ${ }^{6}$ Such research has led us to see that although some myths are indeed "the spoken correlative of things done," as Harrison insisted, there are fundamental differences between myth and rite that obviate the ritual theory. "The truth is," G. S. Kirk has recently observed, "that myths seem to possess essential properties-like their fantasy, their freedom to develop, and their complex structure-that are not reproduced in ritual and suggest that their motive and origin are in important respects distinct" (25). Frazer himself, despite a certain positivist disdain for religion that led him to repudiate both Robertson Smith and the Cambridge group (Ackerman), is viewed by many folklorists as responsible for the confusion introduced by the ritual theory: "The fact is that he was not clear on the difference between fable and cult when he began to write The Golden Bough. . . . he gave cult an absolute priority over narrative, and viewed all cult from the peculiar vantage of a classicist, which does not in any case give a very full or unobstructed prospect of either cult or fable." (Bynum 158, 160; on the "ritual fallacy," see 149-254. An earlier folklorist critique is Bascom's "Myth-Ritual Theory.")

The work of Harrison and her adherents is well known for its concept of the original myth, the mono-myth from which all other myths descend and diverge: the divine king who must be sacrificed so that his society may prosper. A decisive, perhaps fatal blow to this theory came from Joseph Fontenrose in his 1966 critique of the Cambridge group and its later adherents. In its own sphere this book does what Else's nearly contemporaneous series of lectures does in the study of tragedy. Fontenrose reviews the case made by Andrew Lang in Magic and Religion (1901) that Frazer's theory was wholly based on misrepresentation or exaggeration of the evidence. We thus encounter a parallel between the ritual theories of myth and tragedy, in that although specialists had long ago repudiated the principal facts and assumptions supporting the theory, it nonetheless continued to be nourished by literary critics (Fontenrose singles out Lord Raglan and Stanley Edgar Hyman as principal offenders). "In all the ancient world [Greece included] we find no record, clear or obscure, of an annual or periodic sacrifice of divine kings" (8). The anecdote of the "king of the woods" in the grove at Nemi, Frazer's one clear instance of a king put to death when his strength fails, proves to have been an Italian folk custom that cannot be documented as involving the murder of a king (36-49). There is no ethnographic evidence, moreover, of any society anywhere in the world practicing the periodic sacrifice of a king. Well-known instances of a tribe's killing its kings in Africa cannot be used to support the mono-myth: these executions are not conducted periodically - they usually occur when the king is too old to govern-and they are not enacted ritually (9-13). Thus, what Frazer's early readers believed to be a truth grounded on historical and anthropological facts ought rightly to be recognized as a fiction about primitive life. Although Joyce, Eliot, and D. H. Lawrence appear to have credited Frazer's theory with as much historicity as did Harrison, Murray, and Cornford (see Vickery, Literary Impact), any myth critic has to admit that the assumptions behind, say, the notes to Eliot's Waste Land have lost much of the authority that they had a half century ago. Northrop Frye's recent apologia on the subject employs a rather qualified language compared to some of his earlier statements on the subject:

Frazer demonstrated the existence in the human mind of a symbolism often latent in the uncon- 
scious, perhaps never emerging in any complete form, but revealed through many ritual acts and customs, of a divine man killed at the height of his powers whose flesh and blood are ceremonially eaten and drunk. This symbolism expresses the social anxiety for a continuity of vigorous leadership and sexual vitality, and for a constant renewal of the food supply, as the bread and wine of the vegetable crops and the bodies of eaten animals are symbolically identified with the divine-human victim.

("Expanding Eyes" 111-12; italics mine)

Divine king has become a "divine man," but the critic at least saves the appearances of consistency with his earlier opinion of Frazer and his view of The Golden Bough as key to the origins of drama: "it reconstructs an archetypal ritual from which the structural and generic principles of drama may be logically, not chronologically, derived. It does not matter two pins to the literary critic whether such a ritual had any historical existence or not" (Anatomy 109).

This tendency to dismiss the question of Frazer's historicity (certainly Frazer, Harrison, and even Murray believed that they were recovering evidence of things that had really happened) is a disturbing feature of much myth-and-ritual theory. Those who apply the theory seldom admit that it has no basis in fact. Anne Righter, in her justly acclaimed Shakespeare and the Idea of the Play, speaks in factual terms about the resemblance of the murdered York in Henry VI to Frazer's ill-fated king:

The story has reverberations that are even older than the mocking of Christ, echoes that call up the Golden Grove at Nemi and the whole problem of the temporary king. Many primitive societies, reluctant at last to slay the true king, as custom demanded, habitually elected a substitute ruler who took the ritual death upon himself in return for a brief reign.

(106)

Yet Fontenrose has shown the wholly fictitious nature of Frazer's King of the Woods and the thin ethnographic evidence for the periodic sacrifice of a king (Ritual 36, 8-14). If this kind of thing never really happened, where does such a theory come from? If Frye's theory of drama and myth "may be" logically derived from a never-observed archetypal ritual, may it also not be derived? The strange, terrible specificity of the young man killed and eaten contrast sharply with the obscurity of a symbolism that according to Frye not only remains "latent in the unconscious" but has perhaps never come out of the incubator.

\section{II}

The potential fallacy of ritual origins is seriously compounded by the likelihood that "ritual" will be applied with no serious reflections on the exact meaning of the word. Critics using "mythic" to bestow value on a literary text (a practice noted well before Frye's Anatomy; see Wallace Douglas 127) have often done the same with "ritual." Yet the nature of ritual has evaded even social scientists and theologians during the past decade. ${ }^{7}$ Scholars still debate, for example, whether rituals are independent of the social structure or whether they make statements about the relative status of persons in society (Crocker 48). Edmund Leach prefers to think of ritual as, narrowly, "a body of custom specifically associated with religious performance" but, more generally, "any noninstinctive predictable action or series of actions that cannot be justified by a 'rational' means-to-end type of explanation" (520-21). The latter definition has the advantage of incorporating the psychiatrist's sense of personal or private ritual, but some have doubted the appropriateness of this word to describe individual compulsive or idiosyncratic behavior, since "ritual" has traditionally referred to a social and communicative activity (Burkert 49; see also Thomas J. Scheff's critics, who are quoted on pp. 490-500 of his article). Viewed as implying compulsive behavior, the word still has connections with the rough-and-ready formulas of early twentieth-century psychiatric thought. If the study of myth and folklore has led us to understand that an apparently similar myth should not be interpreted identically for all cultures (Ferris 265), the same must be true of ritual, in which the symbols and structures are at least as arbitrary. For this reason, to associate "compulsive" or highly systematic literary structures with ritual, as Fletcher does in linking allegory and ritual, represents a straining of the word, if not a complete misapplication. ${ }^{8}$

Scheff has used another psychological definition of ritual—"the distanced reenactment of 
situations which evoke collectively held emotional distress"- to establish a theory of catharsis in drama by working from the assumption (debatable, as we have seen) that drama is in its origins ritualistic ("Distancing" 489; the theory forms the basis of Scheff's Catharsis). Critics of this theory have rightly noted that the definition neglects the positive, celebrative role of ritual; the theory also requires that social institutions be interpreted in terms of individual behavior, despite massive evidence that the influence is in the opposite direction. Whatever contributions psychology has made to criticism have not been made in association with ritual. It might even be said that an unexpected consequence of the whole literature-as-ritual approach has been to move literature from the province of the self, making us more aware of the "world" of the play or poem, outside the confines of the author's or reader's psyche. If only psychoanalytic critics would admit the deficiencies in their concept, much confusion on the topic would disappear.

The most widely discussed work on ritual during the last two decades approaches the subject as a purely communal act. Victor Turner has described ritual as "prescribed formal behavior for occasions, not given over to technological routine, having reference to beliefs in mystical beings or powers" (Forest 19; cf. Goody). This definition lies behind Geoffrey Hartman's usage quoted in the beginning of this article, and it has won many adherents. The inclusion of "beliefs" in Turner's account would seem to limit the term, more than Leach's definition does, by excluding such formal gestures as handshaking, not to mention animal and insect "rituals" (on such rituals see LaFontaine and Discussion of Ritualization). In this view, however, it is the belief that effects the communal bonding that ritual achieves. Turner, in his study of the Ndembu people in Africa, observes that rites oblige the participants to undergo a change in social status, in which they momentarily exchange their established place in the social structure for a condition of "communitas." During this state the bonds are "anti-structural in that they are undifferentiated, equalitarian, direct..." (Dramas 46-47). Structure, rank, and social and economic status are what hold people apart; "communitas" unites people across the barriers.
Following Arnold Van Gennep's classic Rites of Passage, Turner calls this state of being outside the categories of ordinary social life "liminality" - literally "thresholdness"-explaining that it can occur both in the state of communitas and in a condition of solitude away from society (Dramas 52-53). Acknowledging these two kinds of liminality may explain why "ritual" feelings or expectations are attributed to some literary works-feelings that can be identified with the timeless, dislocating effect that is perhaps essential, but is not peculiar, to ritual. Margaret Mead thus defines ritual as "the repetition of those symbols which evoke the feeling of that primordial event which initially called the community into being with such power that it effects our presence at that event-in other words, represents the primordial event" (127). This feeling can, however, be evoked by other than ritual means. Neither Mead nor Turner, I should note, equates ritual with the festive spirit, as scholars do in studies that follow the lead of C. L. Barber's Shakespeare's Festive Comedy, where "puritan" antiritualism is opposed to the natural impulse toward the celebrative and saturnalian. In the wake of the nostalgia for our primitive past developed by Mircea Eliade, Roger Callois, and others, we should keep in mind that not all primitive people indulge in saturnalian release during festivals; some behave quite otherwise, in fact (Isambert).

At the same time that rituals help us rise above personal and social limitations, even above time and space, they also work, as Mary Douglas argues, to strengthen social status and respect for authority. This function is attested in rites of passage for adolescents throughout the world. According to Turner, this paradoxical effect results from the continuing cycle of "social dramas" in which the tension between elements of the "structure" leads to redress in order to reintegrate the disturbed social group-in effect a movement from structure to communitas to (if the rite is successful) renewed structure. The superbly literate and civilized Turner himself occasionally mentions possible applications of his "ritual process" to literature (e.g., Dramas 265). Recently he has suggested that we might profitably think of modern activities that seem ritualistic, like sports and the theater, as "liminoid" rather than liminal. "Many of the sym- 
bolic and ludic capacities of tribal religion have, with the advancing division of labor, with massive increase in the scale and complexity of political and economic units, migrated into nonreligious genres." Liminoid events are not necessarily collective; they are usually produced by known, named individuals. Although separated from the work place, they are unrelated to "calendrical or social-structural cycles or crises in social processes." Turner leads us to consider the presence of liminal experiences in literature rather than the structure of literature as ritual:

If we focus, for example, on the liminoid genres of literature, on scenes and moments famous for the quality of their communitas and flow, such as Achilles's encounter with Priam in the Iliad, the episode of Raskolnikov's and Sonya's long, painful discovery of one another in Crime and Punishment, so well discussed by Paul Friedrich, the communitas of the liminary outcasts, Lear, Tom O'Bedlam, Kent, and the Fool in the scene on the heath in King Lear, in the serious vein; and the woman's communitas in Aristophanes' Lysistrata, and many episodes in Tom Jones, Don Quixote, and other "carnivalized novels," in the ludic, my hunch is that there will be key symbols which "open" up the relationship to communitas.

("Variations" 52) ${ }^{9}$

Florence Falk has recently applied the theory to A Midsummer Night's Dream, showing how the Athens-woods-Athens sequence resembles that of structure-communitas-structure. (For other uses of Turner and Van Gennep, see Boose.) Yet in this, as in so much similar criticism, we may be left feeling that we have been told what we already knew-though no doubt our knowledge can be sharpened and clarified. Shakespeare very likely has more to teach the anthropologists about ritual than he or even his audiences could learn from them.

\section{III}

Reviewing some of the criticism that has used the concept of ritual during the past decade, we may appreciate the advantage of a precise and informed notion of the subject. Studies of drama especially can benefit from a socially grounded theory like Turner's. Often those who speak of drama as rite neglect these social implications, emphasizing instead the mere feeling of transcen- dence or the "flow" of liminal and liminoid activities alike. Jackson Cope writes of the timeless quality inherent in both ritual and drama:

'Ritual,' I take it, is a ceremonial order of acts which at first level imitates; that is, it re-enacts an established pattern. But at its second level of definition, ritual demands that this conservative reenactment be really efficacious, effective in its repetitions as it was in its origins. Thus ritual is a present act which historically recalls the past for the purpose of reordering-even predetermining - the future. But that present moment of re-enactment merges into the future, and so makes the efficacy of predictive action inevitable as its pattern evolves from contingency into control. In short, ritual is a prediction which, completed, fulfills itself.

This definition appears carefully designed to bring ritual into perfect accord with the aims and province of art. A tragedy of kingship, for example, will repeat the original king's moment of pathos with a view to evoking in the audience those feelings that once were or should have been. Thereafter no one will regard the king apart from the original pathos of the dream time. "Know ye not, I am Richard the Second?" Shakespeare's queen is reported to have said. Such a conception, encompassing as it does the long-acknowledged capacity of art to mediate between the historical and the ideal, is too broad to be serviceable. To further delineate the boundaries of rite and art, I have already mentioned the possibility of ritual drama, a special form that appeals to the audience chiefly in its use of symbols rather than in imitated actions. It is these symbols that evoke the necessary community of belief.

Much comment on the union of rite and drama has occurred in the field of medieval theater, especially since the influential findings of Hardison and Wickham on the subject. Confuting the idea that English religious and secular drama evolved out of Christian worship-a theory quite compatible with Frazer and the Cambridge school, as the writings of E. K. Chambers show-these two scholars have proved the existence of two distinct, largely independent dramatic traditions in the Middle Ages: "the drama of the Real Presence within the liturgy" and "the imitative drama of Christ's humanity," in Wickham's terms (314).$^{10}$ During the 1960 s, how- 
ever, one still encountered the view that the mystery play is based on rite, so that the audience and the actors "shared the same ritual world" during performance, "a world more real than the one which existed outside its frame" (Righter 21). We now see that although there was a shared belief in the transcendent meaning of the events enacted, the principal effect of, say, the grisly realism of the York Crucifixion is to draw the audience closer to the event not through symbols but through representation of recognizable human experiences, familiar human types. In an important article Martin Stevens aids our perspective on the separation of rite from drama and even raises doubts whether the Mass ought properly to be considered dramatic. ${ }^{11}$ Following Brecht, Stevens proposes that drama, unlike rite, consists of enacted illusion; even "ritual drama" if performed in the church would lose ritual aspects entirely. Thus the sense of shared belief, the possibility for communitas, would be emptied from such "liturgical drama" as the Easter visitation at the tomb, which was performed as part of the Easter rite at a stylized sepulcher within the church. If a "play" cannot be staged without becoming representational drama, then ritual plays of the Yeatsian type would seem impossible. Although the persistence (documented by Hardison) of liturgical drama centuries after the establishment of "competing" mystery plays indicates that two entirely different sets of needs were being met (and the persistence of rites would of course add a third), many scholars still maintain, like Stevens, that rite and drama are mutually exclusive. "It is quite evident," writes Gauvin, using a concept resembling Mead's and Turner's,

that a rite is composed of both the prescribed gesture and of its theological significance, which goes far beyond that. In Catholic liturgy the gesture has a deep symbolic and mystic value: it actualizes, in the present time of the ceremony, a past or future event that is thus mysteriously recreated or anticipated. The Catholic rite par excellence is the Mass, which can be said to reconstitute systematically the mystery of the Redemption by the death and Resurrection of Christ.

(131; my trans.) ${ }^{12}$

To equate theater with ritual is therefore to say that theater recreates in the present that which it represents. This position, Gauvin believes, entails two untenable consequences for the English mystery plays: first, that these dramas-ceremonies are truly religious, though conducted by laymen; second, that the persons represented, including the Father and the incarnate Son, are not disguised actors but themselves. Perhaps, he concludes, the cycle plays and other religious representational drama (presumably including liturgical drama, if no play can be a rite) are best classified with devotional images. They do not stand in place of the Mass or any other rite, but they do arouse devout feelings in the viewer, just as a statue or a painting does (138-39; Hanning also argues the theological impossibility of ritual drama). The dramatic element of playing or pretending, however, is quite at odds with the nature of ritual, in which participants act for a purpose (to become adults, to join in marriage, to receive the eucharistic elements).

Twenty years ago a critic struggling with the supposed ritual element in Shakespeare's plays could say, "I shall not be arguing that imaginative works are rituals in disguise, nor (save of course for the cases like Greek tragedy or medieval miracle plays, where it is already common knowledge) that they derive from rituals or explain or justify them. Such extravagances would be absurd" (Holloway 176). Yet at the outset we saw that some respectable scholars do speak of some literary works as rituals; we have also seen that the ritual origins of Greek and medieval theater are no longer accepted as "common knowledge," at least not among specialists in these fields. Hallett Smith's criticism of ritualist approaches to Shakespeare's late plays proceeds from a view similar to Gauvin's: that the plays inhibit the participation essential to true ritual because their theatricality distances the audience (197-202). As with studies of other literature, so with Shakespeare, the decline of myth criticism seems to have brought a waning of enthusiasm for the ceremonial element in the plays, at least as they are construed through the dubious methods of the Cambridge school. ${ }^{13}$ The influence of the Christian liturgy is another matter, and it is the focus of Coursen's lengthy study of the tragedies (Hassel also examines drama and liturgy of the period). Coursen believes that Shakespeare conceived both comedy and tragedy in terms of the com- 
munion service, comedy working toward communion while "The tragic world divorces itself from the unifying powers expressed in communion" (34). The tragedies thus present an array of counterrituals like the murder of Caesar or Richard II's parting from his queen, which Coursen views as an "anti-marriage" (77). Since the audience is not participating in these actions, they can of course be considered rites only from the characters' standpoint. And if we reflect on Victor Turner's definition, we have to add that these moments of disunion are not prescribed or occasioned. We may compare the recent claim that the nunnery scene in Hamlet is an "inverted marriage ceremony," in which Ophelia "violates the ritual" by siding with her father rather than with her potential husband (Boose 329)..$^{14}$ From the audience's perspective such scenes may be symbolic, but (again) the audience does not participate in them; to the characters they are not rites but quite real sets of actions. It is true that Brutus wants to make Caesar's murder an act of sacrifice, but that effort would seem the result of Brutus' special derangement. ${ }^{15}$ An approach tying the plays to the Book of Common Prayer invites a return to earlier theories of drama and ritual as performative equivalents, a path fraught with difficulties. The tradition of the masque, however, should be sufficient to silence those who uncompromisingly separate rite from drama in this period. Jonson's masques especially disclose a sense of drama in the antimasque (when the characters show no awareness of the audience); yet they also contain a ceremonial sense in the mythological-symbolic trappings of the major figures, who mingle with the spectators in dance (see Orgel).

Criticism of narrative during the past decade has been influenced by ritual theories, though not quite as strongly as drama has been. Frazer's ideas inspired a number of modern authors to weave into their stories rites of rebirth, baptism, initiation, and so forth. Among novelists, D. H. Lawrence is especially fascinated with the idea that, as one critic puts it, "ritual as an organizing principle in the novel could link the pattern of an individual's life with that of society at large, and, beyond that, with Nature" (Ross 6). Lawrence's reading of Jane Harrison's Ancient Art and Ritual, Eliot's acquaintance with Jessie
Weston, and of course the widespread interest in Frazer led to that deliberate infusion of ritual into fiction which John B. Vickery explores amply in The Literary Impact of The Golden Bough. Critics of such myth-dominated fiction would probably gain from careful thought about its ritual content. It is well to see John Updike's The Centaur as a series of mythic and timeless moments experienced by a father and relived by his son; but is it true that "By its transformation of a particular situation into a paradigm, myth makes rite dynamic and meaningful" (Vargo 459)? This statement implies that rites consist of details that cannot be "meaningful" without a mythic content. Yet we have seen that rites often exist without myths and that rites, being constituted of symbols, still convey meaning. We shall return later to this widely held assumption that ritual is inferior to myth, often because it is supposed prior to myth. In one of Faulkner's stories, the fact that a cardplayer throws the game supposedly signifies the victory of ritual as "a formal agent of hidden necessity" over game, the "formal agent of apparent freedom" (Zender 59 ; in fact, game is often defined in terms of social necessity [see n. 2, below]). Faulkner, the critic says, "is concerned with the tension between the predetermined movement of characters through a pattern analogous to a traditional myth or ritual, and their free movement in an invented dramatic action" (53). Zender seems to mean that the freedom we exercise contrasts with the predetermined part of our lives, which is a ritual. But the card game is "analogous" to ritual at best, for the program of fated action is like a rite only in that it is prescribed. There is no sense that the one who throws the game does so for communal purposes-to guarantee the harvest or restore the vitality of his community. In all likelihood the claimed association of ritual with "hidden necessity" was suggested by the role of the Fates in a ritualist theory of Greek tragedy. Even in the most familiar kind of fiction involving rites-stories of initiation like Faulkner's The Bear or Dickey's Deliverance-we should ask whether the stories are "rites of passage" when in fact they are about human lives in which initiation occurs. ${ }^{16}$ By contrast, in many real initiation rites there is no myth or story involved, only a series of arbitrarily chosen and ordered symbols for the initiate. 
In summary, despite the careful work of anthropologists, classical scholars, and others who aim to disentangle the term from irrelevant and dubious associations, much criticism has continued to tie literature with an imprecise concept of ritual. The major problems seem to be the tendencies to equate rite with literature because of literature's emotional effects, its use of the symbol, its performative features, and its creation of a sense of kinship with fictional characters and hence with humanity at large. An uninformed, Cambridge-style ritualism also continues despite the efforts of Fontenrose, Else, and others. A 1981 study of the Soviet novel assumes a ritual theory of myth to show that the triteness and predictability of these novels shape them into "a sort of parable for the working-out of Marxism-Leninism in history" (Clark 9). ${ }^{17}$ Especially in view of the communal roots of ritual, one may ask whether it makes sense to think of the lonely novel reader entering into a ritual of anything.

We should not deny the usefulness of some recent criticism aimed at the discovery of ritual content. I have already noted the rites embedded in Lawrence's stories. One recent study proposes that the setting of Joyce's "The Dead" is not a New Year's party but a funeral celebration featuring the "dance of the dead," a rite noted by Van Gennep and mentioned in one of Joyce's poems (J. W. Foster). John Vickery analyzes the pattern of the scapegoat ritual in the work of several authors whom we have every reason to believe were fully aware of this material ("Scapegoat"). (In the same collection, however, a recanting ritualist offers a caveat on interpreting quest narratives like Gawain and the Green Knight as rites of passage [Moorman, "Comparative"].) ${ }^{18}$ The demonstrable influence of Nietzsche moved André Gide to construct L'Immoraliste around "symbolic rituals of death and revival" and to have his hero pass through rebirth and "a pagan-like cleansing ceremony in which sun, water, and a variation of tonsuring are used" (O'Reilly). Frazer's influence may also have indirectly moved Christian authors to incorporate their ceremonies into their works. In one of Charles Williams' "liturgical novels," The Greater Trumps, a character discovers that the Christian service in her village is part of a hidden cosmic dance, a means to participate in the universal delight that leads to mystic ecstasy (Manlove 169).19 Such narratives not only contain rituals, they are about them, about the feelings they generate and the needs they serve, so that we may justly speak of a ritual ambience in these works, if not quite a ritual form.

It need hardly be said that this projection into narrative and drama of details suggesting religious worship owes much to the nineteenthcentury dream of a cult of art that would supplant traditional religion. This familiar theme takes various forms in Arnold, Nietzsche, and Joyce, who has Stephen Dedalus expound such a theory near the end of Portrait of the Artist. Renouncing Catholicism, Mallarmé nevertheless tries as Joyce does to retain a sense of the sacred through invented rites in his work (see, e.g., Danahy). Karl Beckson traces the course of British religious aestheticism in Yeats's "infallible church of poetic tradition," in the poets Lionel Johnson (who believed that "Life should be a ritual") and Ernest Dowson, and in the novels of Walter Pater (Marius the Epicurean) and Frederick Rolfe (Hadrian the Seventh). So many scholars still believe that "literature in man's historical evolution was once religious liturgy and dance, charms and oracles" (Ruland 119 ), that the "mythology of aestheticism" is often taken for granted by both the religious and the nonreligious. ${ }^{20}$ Such assumptions are evident in the typical late twentieth-century observation that $A$ Midsummer Night's Dream, although a secular play, embodies "more successfully than the religious and folk traditions, an extra-temporal moment of achieved harmony in human life, a triumph formerly shared with ritual, now in the sole possession of the work of art" (Vlasopolos 29).

A major voice of the past decade, questioning older theories regarding literature, especially drama, and the ritual process, has been René Girard. Following Freud in Totem and Taboo, Girard proposes that a primal killing threatened to destroy human community through successive retributions. This violence could be avoided only by the appointment of a scapegoat who would receive the full force of the community's wrath. The sacrificial victim becomes a characteristic human expedient and "constitutes a major means, perhaps the sole means, by which men expel from their consciousness the truth about 
their violent nature - that knowledge of past violence which, if not shifted to a single 'guilty' figure, would poison both the present and the future" (Violence 83). In all human relations, Girard sees three figures locked in a circle of "mimetic desire": the subject, the rival, and the object. "The subject desires the object because the rival desires it" (146). A telling instance is Shakespeare's Troilus and Cressida, in which the Greeks want Helen back because the Trojans have taken her away and the Trojans want to keep her because the Greeks want her back ("Shakespeare's Theory" 113). Mimetic desire is "the immediate interplay of imitating and imitated desire. Mimesis generates rivalry, which in turn reinforces mimesis" (Double Business 53).

The scapegoat process gives birth to a vast array of myths and rituals, all of which serve merely to conceal the ugly facts of the surrogate victim sacrificed to this mimetic, desire-caused violence. Since myths exist to rationalize the scapegoat mechanism, mythology is little more than "a text of persecution" that rituals exist to enact ("Interview" 40): "Ritual is nothing more than the regular exercise of 'good' violence" (Violence 37), that is, violence that will prevent the spread of retribution or revenge and similar kinds of hostility throughout the community. Like almost all culture, drama originates in violence: "All religious rituals spring from the surrogate victim, and all the great institutions of mankind, both secular and religious, spring from ritual. Such is the case . . . with political power, legal institutions, medicine, the theater, philosophy and anthropology itself" (Violence 306). By "religion" Girard here means primitive religion as opposed to the beliefs of the Hebrew prophetic books and the Gospels (a point he makes clear in Des choses 178).

Although to skeptics his theory must seem a quaint throwback to mono-myth, Girard, like Frye, has built his hypothesis on an intricate theoretical structure. A fundamental principle is social differentiation: "Order, peace, and fecundity depend on cultural distinctions," the loss of which gives birth to rivalries and violence (Violence 49). Thus in Troilus, "degree" is what "permits individuals to find a place for themselves in society" $(50)$. The final annihilation of differences can only lead to the triumph of the strong over the weak in a Hobbesian state of nature (51). This view accounts for the frequent concern in Girard's work with myths of twins or doubles (Cain and Abel, Romulus and Remus, Eteocles and Polyneices). Our modern loss of differences is attested by the change from these ancient myths of warring twins to the modern concept of affectionate family relations (61). Girard attacks the structuralist notion, shared by Lévi-Strauss and Frye, that literature and myth deal with differentiation, while ritual searches for an "undifferentiated immediacy." In fact both ritual and myth tend to destroy difference ("Shakespeare's Theory" 109, "Lévi-Strauss"). "The sacred concerns itself above all with the destruction of differences, and this nondifference cannot appear as such in structure" (Violence 241). Thus what Nietzsche called the "Dionysiac" state must aim to "erase all manner of differences: familial, cultural, biological, and natural" (160).

When the sacrificial rites disappear, at a time coinciding with the loss of the difference between "good" and "bad" violence, difference cannot be reasserted as it was each time on completion of the old rites. We then have a "sacrificial crisis," a time of deterioration for the system by which reciprocal violence is channeled off. When we "demystify" religion, our doing so "necessarily coincides with the disintegration of that system. ... In fact, demystification leads to constantly increasing violence, a violence less 'hypocritical' than the violence it seeks to expose, but more energetic . . . a violence that knows no bounds" (24-25). Euripides' Bacchae concerns just such a crisis (126-42). Thus, while for Turner rites exist to instill a sense of communitas, of values shared across social boundaries (especially when violence threatens), Girard believes that rites are used to redirect violence. Violence, however, is the inescapable condition of society.

These ideas have particular relevance to drama, since drama, especially the great tragedies of the Greeks, "is by its very nature a partial deciphering of mythological motifs" (64). In Sophocles and Euripides (as later in Shakespeare), the poet at certain moments "lifts the veil long enough for you to glimpse the long hidden historical truth that lies at the origin" ("Interview" 35; this is the interviewer's para- 
phrase). Even though tragedy originated in ritual, the inspiration of a play like Oedipus Rex is "essentially antimythical and antiritualistic" (Violence 95). In "Myth and Ritual in Shakespeare's A Midsummer Night's Dream," Girard warns Shakespearean critics of the myth-ritual school to reconsider their assumptions: "Instead of viewing myth as a humanization of nature, as we always tend to do, Shakespeare views it as the naturalization as well as the supernaturalization of a very human violence. Specialists on the subject might be well advised to take a close look at this Shakespearean view; what if it turned out to be less mythical than their own!" (200-01; the word "ritual," although it appears in the title, scarcely appears in the essay itself). In the same essay, Girard proposes that $A$ Midsummer Night's Dream is a drama of mimetic desire in which the self idolizes the "other" for the sake of the self-in effect, the self mythologizes the other. This play shows that the myth always captivates sooner than the truly human does; thus, in The Merchant of Venice, where the same rules operate, Bassanio falls in love with Portia's picture, not with Portia.

It is in a recent essay on this play, in fact, that Girard offers by implication a way of resolving some of the confusion inherited from the past about ritual and literature. Ritual may inhere thematically, structurally, or, in certain special cases, affectively, by a deliberate appeal to audience participation. Girard sees The Merchant of Venice as a play about revenge and retribution, with Shylock as the "grotesque double" ("To Entrap" 105) of Antonio. He points out the telling evidence of Portia's question when she enters the courtroom, "Which is the merchant and which is the Jew?" The classic Jew of European anti-Semitism, Shylock is widely recognized as a scapegoat, hence his doubling in the play. Yet, Girard asks, should we see scapegoat as theme or structure here? If scapegoat is theme, the author will actually realize the evil of the scapegoat mechanism, as did the Greek tragic dramatists; if structure, though, the scapegoat ritual will be "a passively accepted delusion" of the author (109). In Girard's view Shakespeare, like the Greeks, fully intends his meaning-scapegoat is theme; but for those unable to be reached by Shakespeare's meaning, there is also a scapegoat structure. Finally a special quality of The Mer- chant of Venice that evokes the audience's wishful participation gives the play what Turner would call its "liminoid" characteristics. "The crowd in the theater becomes one with the crowd on the stage. The contagious effect of scapegoating extends to the audience" during the trial scene, when "the presence of the silent Magnificoes, the elite of the community, turns the trial into a rite of social unanimity" (111). The crowd involvement in Julius Caesar is similar; in all such examples drama merges almost totally with ritual.

In Girard's view, the great tragedies signal a reaction against the excess of communality in ritual by asserting the claims of the suffering individual compelled by a socially determined necessity. Girard is always careful to admit that his hypothesis about human desire and the scapegoat mechanism is just that, and he denies that he is working toward a universally applicable "theory of literature." Although I cannot offer here a critique of his hypothesis, I might suggest that the equation of ritual with sacrifice (and therefore with the scapegoat process) narrows the concept excessively. Nevertheless, Girard's position does furnish a serviceable alternative to the familiar view that all literature gains profundity or beauty from a touch of the ritualistic.

\section{IV}

If there have been great authors who found the ritual sense dangerous or irrelevant (in Madame Bovary it is even a refuge for banality and superstition) there have always been those who have sought to recover that sense. Charting this recovery in the novels of George Eliot, Barbara Hardy calls to our attention a passage from Daniel Deronda:

The most powerful movement of feeling within a liturgy is the prayer which seeks for nothing special, but is the yearning to escape from the limitations of our own weakness and an invocation of all Good to enter and abide with us; or else a selfoblivious lifting-up of gladness, a Gloria in Excelsis that such Good exists; both the yearning and the exultation gathering their utmost force from the sense of communion in a form which has expressed them both, for long generations of struggling fellowmen. 
What George Eliot conveys here is an appreciation of the flow and communitas that Turner finds in ritual, for the worshiper joins both other human beings and his or her ancestors in a momentary "time out of time." "Human feeling," Barbara Hardy observes, "is given clarity and definition by ritual, and shown at crucial moments to feel itself a part of a larger tradition" (14). Instead of attempting to bring ritual and literature together, she suggests reasons for appreciating their difference. Ritual is really "the ground, the bass," in much fiction, while "counterpointed against it is the change in feeling and circumstance" necessary in a novel or play (9).

Geoffrey Hartman's description of Faust as a ritual may be ascribable to the "liminoid" relation between the sacred and secular that Turner discusses. Art "seems generically and ambiguously involved with the sacred and profane ..."; "it is always inauthentic vis-à-vis a thoroughgoing realism" (Beyond Formalism 21-22). Elsewhere in the same book, thinking of the romantic period, Hartman says, "There clearly comes a time when art frees itself from subordination to religion or religiously inspired myth and continues or even replaces them." $\mathrm{He}$ sees Faust, in fact, as attempting to "bridge the gap between the myth-centered age of romance and the modern spirit" $(305,310)$. Hartman proposes the evolutionary continuum in a critique of the "structuralist adventure," the program that in many respects includes Frye and that would reject Hartman's distinction between ancient and modern art, primitive and civilized mind. Understanding the testament of ancient art has been a task of modern civilization since the inception of the "modern," and a share of the task has been to discover the place of ritual in art. In literary thought, this enterprise begins not with Frazer's admirers but with the young Nietzsche's Birth of Tragedy. Nietzsche's book met with outrage from his fellow classical scholars, especially from the future prince of $\mathrm{Al}$ tertumswissenschaft, Ulrich von WilamowitzMoellendorff. Twenty-five years later Nietzsche would agree with Wilamowitz in many respects: his first book was "badly written, ponderous, embarrassing, image-mad and image-confused, sentimental, ... a an arrogant and rhapsodic book." $\mathrm{He}$ particularly regretted that "the $\mathrm{Di}-$ onysiac" remained as obscure and elusive a concept as ever. (Silk and Stern 95, 119-20. See also J. B. Foster on Gide, Lawrence, Malraux, and Mann.) The Dionysiac-Apolline polarity, so persistent in ritual conceptions of drama during our century, retains a certain hold on contemporary theater, but in criticism it has been reduced to an instance of the "radical indeterminacy" supposedly at the heart of literary discourse (de Man). The prospects for a fuller understanding of ritual in relation to literature might be improved if we could agree that both these features of cultural life exist in an ecology not unlike what George Eliot proposed, in which subject and object, worshiper and cult, reader (writer) and text acquire meaning only in the context of a community. ${ }^{21}$

\section{University of Kansas}

Lawrence

\section{Notes}

1 The posthumous 1962 edition of PickardCambridge's book omits much of the rebuttal of the Cambridge school.

2 Using terminology borrowed from Richard Schechner, Hinden proposes that classical tragedy moves toward community-from the arena of play and the self-assertive "I" to that of game (the social "we") to the self-transcendent "other" of ritual.

${ }^{3}$ Graham-White cites a number of theater critics who use "ritual" imprecisely. Yet one of these, Richard Schechner, has since developed his ideas impressively in a study of the common features of ritual and theater as recreations of past events or "restored behavior." Jerzy
Grotowski is among the more recent experimenters in the ritualizing of theater (see Findlay).

${ }^{4}$ Yet Herbert Weisinger restricts symbol to art alone: "To speak of symbolic meaning is already to have made the leap from myth to art" (152). I agree with Ernst Cassirer that symbolism is an inevitable human response, whether in art, religion, or politics (41-62).

5 See C. Clifford Flanigan's comprehensive discussions of Christian liturgical drama, which have considerable relevance to my subject.

${ }^{6}$ Reviewing this book, Hyman says Fontenrose is "proudly enrolled under Henri Frankfort's obscurantist banner, in a crusade to undo the last seventy years of 
generalization in comparative mythology by the denial of the ancient Near East as a unified culture area" (127).

${ }^{7}$ See Robert Goodin's strictures on this point (281). Various definitions are proposed in Moore and Meyerhoff, and Roy A. Rappaport's "Obvious Aspects of Ritual" is of great importance.

8 Also questionable is Fletcher's association of "contagious magic" with ritual form (195-99). For the distinction between religion and magic in ritual, see Goody. Wittgenstein remarks that such an act as burning in effigy "is obviously not based on a belief that it will have a definite effect on the object which the picture represents. It aims at some satisfaction and it achieves it. Or rather, it does not aim at anything; we act in that way and then feel satisfied" (4e).

9 "Flow" is a term borrowed from the social psychologist Mihali Csikszentmihalyi, meaning the "holistic sensations present when we act with total involvement," as in religious or creative experience or in sports ("Variations" 48).

10 Francis Edwards' guide for students still speaks of drama as moving "from the confines of the church to the open air" (64).

11 Blandine-Dominique Berger argues against Hardison's view that the Mass is drama. She sees liturgical drama "at the heart of a new type of liturgy" in the Middle Ages (132) but believes that liturgy was not the simple source for Western drama.

12 Mary and Max Gluckman, two social scientists, make a similar point: "When an ancient myth is reenacted in a drama, there is no idea that the events are in any way occurring then and there, with the actors becoming the heroes and heroines of that distant event, and the audience participating in the event itself. The drama is presentation, not a representation as ritual is" (235).

13 Cambridge-style criticism has persisted, however. See Isaacs and Reese and Bryant. The opening section of Robert Weimann's Shakespeare and the Popular
Tradition (1-6) does not inspire confidence when it cites Frazer, E. K. Chambers, and Christopher Caudwell as its principal authorities on the alliance of ritual and theater. Weimann concurs with Hardison's doubts about the evolutionary view but claims that Hardison underestimates "the historical element of change" that links liturgy to Shakespearean drama (271, n. 23). Yet Weimann's opening section, entitled "Ritual and Mimesis," seems to treat "the gradual movement from myth to realism" (3) in evolutionary terms.

14 Boose discusses several such "rituals." Although she cites anthropological studies, she is much influenced by psychological conceptions of ritual, as when she asserts that "What the church service is actually all about is the separation of the daughter from the interdicting father" (326).

15 Ritualist readings of Caesar's murder have continued since Brents Stirling and Ernest Schanzer; see, e.g., de Gerenday's study, which shows the influence of Freud and Erik Erikson.

16 William Stephenson argues the primacy of the inner rite of Drew the artist over the initiation of the "antinomian" rugged hero Lewis. Cf. Lindberg.

17 Clark also observes that "The majority of initiating ordeals more or less clearly imply a ritual death-or at least some token mutilation-followed by a resurrection or new birth. In the Stalinist novel, death and token mutilation have a predominantly mythic function" (178).

18 Moorman reconsiders his earlier "Myth and Medieval Literature."

19 The entire issue of Mosaic in which Manlove's article appears (Winter 1979) is devoted to liturgy and literature.

20 Ruland's bibliographical survey is well informed from the standpoint of both religious and literary studies.

21 This study was supported by a grant from the General Research Fund of the University of Kansas.

\section{Works 'Cited}

Ackerman, Robert. "Frazer on Myth and Ritual." Journal of the History of Ideas 36(1975):115-34.

Arrowsmith, William. Introd. The Bacchae. In Euripides V. Ed. David Grene and Richmond Lattimore. Chicago: Univ. of Chicago Press, 1959, 142-53.

Bascom, William. "The Myth-Ritual Theory." Journal of American Folklore 70(1957):103-14.

Beckson, Karl. "A Mythology of Aestheticism." English Literature in Transition 17(1974) :233-49.

Berger, Blandine-Dominique. Le Drame liturgique de Pâques. Paris: Editions Beauchesne, 1976.

Boose, Lynda E. "The Father and the Bride in Shakespeare." PMLA 97(1982):325-47.
Bryant, J. A., Jr. "Falstaff and the Renewal of Windsor." PMLA 89(1974):296-301.

Burkert, Walter. Structure and History in Greek Mythology and Ritual. Berkeley: Univ. of California Press, 1979.

Bynum, David E. The Daemon in the Wood: A Study of Oral Narrative Patterns. Cambridge, Mass.: Center for the Study of Oral Literature, 1978.

Cassirer, Ernst. An Essay on Man. 1944; rpt. New York: Doubleday, 1954.

Clark, Katerina. The Soviet Novel: History as Ritual. Chicago: Univ. of Chicago Press, 1981.

Cope, Jackson I. The Theater and the Dream: From 
Metaphor to Form in Renaissance Drama. Baltimore: Johns Hopkins Univ. Press, 1973.

Coursen, Herbert N., Jr. Christian Ritual and the World of Shakespeare's Tragedies. Lewisburg, Pa.: Bucknell Univ. Press, 1976.

Crocker, Christopher. "Ritual and the Development of Social Structure: Liminality and Inversion." In The Roots of Ritual. Ed. James D. Shaughnessy. Grand Rapids, Mich.: Eerdmans, 1973, 47-86.

Danahy, Michael. "The Drama of Herodiade: Liturgy and Irony." Modern Language Quarterly 34(1973): 292-311.

de Gerenday, Lynn. "Play, Ritualization, and Ambivalence in Julius Caesar." Literature and Psychology 24(1976) :24-33.

de Man, Paul. "Genesis and Genealogy in Nietzsche's The Birth of Tragedy." Diacritics 2.4(1972):44-53.

A Discussion of Ritualization of Behaviour in Animals and Man. Philosophical Transactions of the Royal Society of London. Series B. Biological Series 251. London: Royal Society of London, 1966.

Dörrie, Heinrich. "The Meaning and Function of Myth in Greek and Roman Literature." Yearbook of Comparative Criticism 9(1980):109-31.

Douglas, Mary. Natural Symbols: Explorations in Cosmology. New York: Random, 1973.

Douglas, Wallace. "The Meanings of Myth" (1953). In Myth and Literature: Contemporary Theory and Practice. Ed. John B. Vickery. Lincoln: Univ. of Nebraska Press, 1966, 119-28.

Edwards, Francis. Ritual and Drama: The Medieval Theatre. London: Lutterworth, 1976.

Else, Gerald F. Origins and Early Form of Greek Tragedy. Martin Classical Lectures, vol. 20. Cambridge: Harvard Univ. Press, 1967.

Falk, Florence. "Drama and Ritual Process in A Midsummer Night's Dream." Comparative Drama 14(1980):263-79.

Feder, Lillian. Ancient Myth in Modern Poetry. Princeton: Princeton Univ. Press, 1971.

Ferris, William R., Jr. "Myth and the Psychological School: Fact or Fantasy." New York Folklore Quarterly 30(1974) :254-66.

Fichte, Jörg O. Expository Voices in Medieval Drama. Nürnberg: Hans Karl, 1975.

Findlay, Robert. "Grotowski's 'Cultural Explorations Bordering on Art, Especially Theatre." Theatre Journal 32(1980):349-56.

-. "Grotowski's Laboratorium after Twenty Years: Theory and Operation." Kansas Quarterly 12(Fall 1980):133-39.

Flanigan, C. Clifford. "The Liturgical Drama and Its Tradition: A Review of Scholarship 1965-1975." Research Opportunities in Renaissance Drama 18(1975):81-102.

- "The Liturgical Drama and Its Tradition: A Review of Scholarship (Part II)." Research Opportunities in Renaissance Drama 19(1976):109-36.

Fletcher, Angus. Allegory: The Theory of a Symbolic Mode. Ithaca, N.Y.: Cornell Univ. Press, 1964.

Fontenrose, Joseph. Python: A Study of Delphic Myth and Its Origins. Berkeley: Univ. of California Press, 1959.

- The Ritual Theory of Myth. Folklore Studies, no. 18. Berkeley: Univ. of California Press, 1966.

Foster, John Burton, Jr. Heirs to Dionysos: A Nietzschean Current in Literary Modernism. Princeton: Princeton Univ. Press, 1981.

Foster, John Wilson. "Passage through 'The Dead.'" Criticism 15(1973):91-108.

Frye, Northrop. Anatomy of Criticism: Four Essays. 1957; rpt. New York: Atheneum, 1967.

_. "Expanding Eyes." In his Spiritus Mundi: Essays on Literature, Myth, and Society. Bloomington: Indiana Univ. Press, 1976, 99-122.

Gauvin, C. "Rite et jeu dans le théâtre anglais du Moyen Age." Revue d'Histoire du Théâtre 29 (1977) :128-40.

Girard, René. Des choses cachées depuis la fondation du monde. Paris: Bernard Grasset, 1978.

. "Interview." Diacritics 8.1(1978) :31-54.

"Lévi-Strauss, Frye, Derrida, and Shakespearean Criticism." Diacritics 3.3(1973):34-38.

- "Myth and Ritual in Shakespeare's A Midsummer Night's Dream." In Textual Strategies: Perspectives in Post-Structuralist Criticism. Ed. Josué Harari. Ithaca, N.Y.: Cornell Univ. Press, 1979, 189-212.

- "Shakespeare's Theory of Mythology." Proceedings of the Comparative Literature Symposium 11(1980):107-24.

- To Double Business Bound: Essays on Literature, Mimesis, and Anthropology. Baltimore: Johns Hopkins Univ. Press, 1978.

- . "To Entrap the Wisest': A Reading of The Merchant of Venice." In Literature and Society: Selected Papers of the English Institute. Ed. Edward W. Said. Baltimore: Johns Hopkins Univ. Press, 1978, 100-19.

- Violence and the Sacred. Trans. Patrick Greg. ory. Baltimore: Johns Hopkins Univ. Press, 1977.

Gluckman, Mary, and Max Gluckman. "On Drama, and Games and Athletic Contests." In Secular Ritual. Ed. Sally Moore and Barbara C. Meyerhoff. Assen, Neth.: Van Gorcum, 1977, 227-43.

Goodin, Robert. "Rites of Rulers." British Journal of Sociology 29(1978):281-99.

Goody, Jack R. "Religion and Ritual: The Definitional Problem." British Journal of Sociology 12(1961): 142-64.

Gorsky, Susan R. "A Ritual Drama: Yeats's Plays for Dancers." Modern Drama 17(1974) :165-78.

Graham-White, Anthony. " 'Ritual' in Contemporary Theatre Criticism." Educational Theater Journal 28(1976):318-24.

Hanning, R. W. “'You Have Begun a Parlous Playe': The Nature and Limits of Dramatic Mimesis as a Theme in Four Middle English 'Fall of Lucifer' Cycle Plays." Comparative Drama 7(1973) :22-50.

Hardison, O. B. Christian Rite and Christian Drama in the Middle Ages. Baltimore: Johns Hopkins Univ. Press, 1965. 
Hardy, Barbara. Rituals and Feeling in the Novels of George Eliot. W. D. Thomas Memorial Lecture. Swansea, Wales: University College of Swansea, 1973.

Hartman, Geoffrey H. Beyond Formalism. New Haven: Yale Univ. Press, 1970.

- The Fate of Reading and Other Essays. Chicago: Univ. of Chicago Press, 1975.

Hassel, R. Chris. Renaissance Drama and the English Church Year. Lincoln: Univ. of Nebraska Press, 1979.

Hinden, Michael. "Ritual and Tragic Action: A Synthesis of Current Theory." Journal of Aesthetics and Art Criticism 32(1974):357-73.

Holloway, John. The Story of the Night: Studies in Shakespeare's Major Tragedies. Lincoln: Univ. of Nebraska Press, 1961.

Hyman, Stanley Edgar. "The Ritual View of Myth and the Mythic" (1958). In Myth and Literature: Contemporary Theory and Practice. Ed. John B. Vickery. Lincoln: Univ. of Nebraska Press, 1966, 4758.

. Rev. of Joseph Fontenrose's Python. Carleton Miscellany 1(1960): 124-27.

Isaacs, Neil D., and Jack E. Reese. "Dithyramb and Paean in A Midsummer Night's Dream." English Studies 55(1974):351-57.

Isambert, F. A. "Feasts and Celebrations: Some Critical Reflections on the Idea of Celebration." Trans. Bernd Jager. Humanitas 5(1969):29-42.

Kirk, G. S. Myth: Its Meaning and Function in Ancient Greece and Other Cultures. Cambridge: Cambridge Univ. Press, 1970.

Kluckhohn, Clyde. "Myth and Ritual: A General Theory." Harvard Theological Review 35(1942): 45-79.

Knox, Bernard. Word and Action: Essays on the Ancient Theater. Baltimore: Johns Hopkins Univ. Press, 1979.

LaFontaine, J. S., ed. The Interpretation of Ritual. London: Tavistock, 1972.

Leach, Edmund. "Ritual." International Encyclopedia of the Social Sciences. New York: Macmillan, 1968, 13:520-26.

Lewis, C. S. English Literature in the Sixteenth Century excluding Drama. New York: Oxford Univ. Press, 1954.

Lindberg, Henry J. "James Dickey's Deliverance: The Ritual of Art." Southern Literary Journal 6(1974): 83-90.

Manlove, C. N. "The Liturgical Novels of Charles Williams." Mosaic 12(Winter 1979):161-81.

Mead, Margaret. Twentieth Century Faith: Hope and Survival. New York: Harper, 1972.

Moore, Sally, and Barbara G. Meyerhoff, eds. Secular Ritual. Assen, Neth.: Van Gorcum, 1977.

Moorman, Charles. "Comparative Mythography: A Fungo to the Outfield." In The Binding of Proteus: Perspectives on Myth and the Literary Process. Ed. Marjorie W. McCune et al. Lewisburg, Pa.: Bucknell Univ. Press, 1980, 63-77.
"Myth and Medieval Literature: Sir Gawain and the Green Knight." In Myth and Literature: Contemporary Theory and Practice. Ed. John B. Vickery. Lincoln: Univ. of Nebraska Press, 1966, 171-86.

O'Reilly, Robert F. "Ritual, Myth and Symbol in Gide's L'Immoraliste." Symposium 28(1974) :346-55.

Orgel, Stephen. The Jonsonian Masque. Cambridge: Harvard Univ. Press, 1967.

Pickard-Cambridge, Arthur. Dithyramb, Tragedy and Comedy. Oxford: Clarendon, 1927.

Rappaport, Roy A. "The Obvious Aspects of Ritual." In his Ecology, Meaning, and Religion. Richmond, Calif.: North Atlantic, 1979, 173-221.

Righter, Anne. Shakespeare and the Idea of the Play. 1962; rpt. Harmondsworth, Eng.: Penguin, 1967.

Ross, Charles L. "D. H. Lawrence's Use of Greek Tragedy: Euripides and Ritual." D. H. Lawrence Review 10(1977): 1-19.

Ruland, Vernon. Horizons of Criticism: An Assessment of Religious-Literary Options. Chicago: American Library Assn., 1975.

Schechner, Richard. "Collective Reflexivity: Restoration of Behavior." In A Crack in the Mirror: Reflexive Perspectives in Anthropology. Ed. Jay Ruby. Philadelphia: Univ. of Pennsylvania Press, 1982, 39-81.

Scheff, Thomas J. Catharsis in Healing, Ritual, and Drama. Berkeley: Univ. of California Press, 1979.

- "The Distancing of Emotion in Ritual." Current Anthropology 18(1977):483-505.

Silk, M. S., and J. P. Stern. Nietzsche on Tragedy. Cambridge: Cambridge Univ. Press, 1981.

Smith, Hallett. Shakespeare's Romances: A Study of Some Ways of the Imagination. San Marino, Calif.: Huntington Library, 1972.

Stephenson, William. "Deliverance from What?" Georgia Review 28(1974): 114-20.

Stevens, Martin. "Illusion and Reality in the Medieval Drama." College English 32(1971):448-64.

Taplin, Oliver. "The Delphic Idea and After: Greek Tragedy on Film." TLS, 17 July 1981, 811-12.

- Greek Tragedy in Action. Berkeley: Univ. of California Press, 1978.

Turner, Victor. Dramas, Fields, and Metaphors: Symbolic Action in Human Society. Ithaca, N.Y.: Cornell Univ. Press, 1974.

- The Forest of Symbols: Aspects of Ndembu Ritual. Ithaca, N.Y.: Cornell Univ. Press, 1967.

- "Variations on a Theme of Liminality." In Secular Ritual. Ed. Sally Moore and Barbara G. Meyerhoff. Assen, Neth.: Van Gorcum, 1977, 3652.

Vargo, Edward P. "The Necessity of Myth in Updike's The Centaur." PMLA 88(1973):452-60.

Vickery, John B. The Literary Impact of The Golden Bough. Princeton: Princeton Univ. Press, 1973.

- "The Scapegoat in Literature: Some Kinds and Uses." In The Binding of Proteus: Perspectives on Myth and the Literary Process. Ed. Marjorie W. 
McCune et al. Lewisburg, Pa.: Bucknell Univ. Press, 1980, 264-78.

ed. Myth and Literature: Contemporary Theory and Practice. Lincoln: Univ. of Nebraska Press, 1966.

Vlasopolos, Anca. "The Ritual of Midsummer: A Pattern for A Midsummer Night's Dream." Renaissance Quarterly 31(1979):21-29.

Weimann, Robert. Shakespeare and the Popular Tradition. Baltimore: Johns Hopkins Univ. Press, 1978.

Weisinger, Herbert. "The Myth and Ritual Approach to Shakespeare." In Myth and Literature: Contemporary Theory and Practice. Ed. John B. Vick- ery. Lincoln: Univ. of Nebraska Press, 1966, 14960.

Wickham, Glynne. Early English Stages. London: Routledge, 1959.

Wittgenstein, Ludwig. Remarks on Frazer's Golden Bough. Ed. and trans. R. Rhees and A. C. Miles. Retford, Eng.: Brynmill, 1979.

Wittreich, Joseph A., Jr. Visionary Poetics: Milton's Tradition and His Legacy. San Marino, Calif.: Huntington Library, 1979.

Zender, Karl F. "A Hand of Poker: Game and Ritual in Faulkner's 'Was." Studies in Short Fiction 11(1974):53-60. 